\title{
THE IMPACT OF 9/11 ON US REIT RETURNS: FUNDAMENTAL OR FINANCIAL?
}

\author{
Andrea GHENO ${ }^{1}$ and Stephen L. LEE ${ }^{2}$ \\ 1 Department of Economics, University of Rome III, Via Silvio D'Amico 111, 00145, \\ Rome, Italy. E-mail: gheno@uniroma3.it \\ 2 Faculty of Finance, Cass Business School, City University, 106 Bunhill Row, \\ London EC1Y 8TZ, UK. E-mail: Stephen.Lee.1@city.ac.uk
}

Received 25 August 2006; accepted 6 November 2006

\begin{abstract}
Following the attack on the World Trade Center on 9/11 volatility of daily returns of the US stock market rose sharply. This increase in volatility may reflect fundamental changes in the economic determinants of prices such as expected earnings, interest rates, real growth and inflation. Alternatively, the increase in volatility may simply reflect the effects of increased uncertainty in the financial markets. This study therefore sets out to determine if the effects of the attack on the World Trade Center on 9/11 had a fundamental or purely financial impact on US real estate returns. In order to do this we compare preand post-9/11 crisis returns for a number of US REIT indexes and in general we find that the effect of the attack on the World Trade Center on 9/11 had only a financial effect on REIT returns and therefore was transitory.
\end{abstract}

KEYWORDS: 9/11; REITs; Fundamental or financial effects

\section{INTRODUCTION}

The volatility of daily returns of the US stock market rose sharply following the terrorist attack on the World Trade Center. This increase in volatility may reflect changes in the fundamental economic determinants of stock prices such as expected earnings, interest rates, real growth and inflation. Alternatively, the increase in market volatility after the $9 / 11$ terrorist attacks may simply reflect the effects of increased uncertainty in the financial markets.

For instance, Baen (2003) argues that the terrorist attack added another dimension to property investment risk in the US that is likely to have serious implications for the future capital values and net operating income (NOI) to institutional, investment-grade real estate. Indeed, Kelly (2001) argues that the impact of $9 / 11$ on real estate markets would be felt across the whole of America. This suggests that the effects of the attack on the World Trade center are likely to be fundamental and long lasting for real estate securities.

In contrast, in an analysis of the causes of large daily price changes, Kaminsky and Schmukler (1999) argue that the largest daily changes seem to be driven in part by herding or an overreaction to bad news. While, Wrolstad and Kreuger (2003) find that, as ex-

International Journal of Strategic Property Management ISSN 1648-715X print / ISSN 1648-9179 online (C) 2006 Vilnius Gediminas Technical University http://www.ijspm.vgtu.lt 
pected, when catastrophic events such as the attack on the World Trade Center, occur, investor risk aversion increases dramatically but that the increase was only short lived as within a month the market had regained the losses incurred immediately after the $9 / 11$ events. In other words, the 9/11 attacks had only a financial impact on real estate security returns and was therefore short lived as the assessment by investors of the effects of the terrorist action on the economic prospects of the economy evolved. In support of this view Miller et al (2003) find that there was no significant increase in vacancy rates in tall and trophy buildings across the major cities of the US, even though New York showed modest and negative effects on vacancy rates. While, survey evidence reported by Miller et al (2003) indicated that the impact on tall and trophy buildings should show little lasting effects, although the truly famous buildings have suffered as a consequence of 9/11 (Dermisi, 2005).

In order to sort out whether the effects of the attack on the World Trade Center on 9/11 had a fundamental or purely financial impact on US real estate securities we compare preand post-9/11 crisis returns for the US Real Estate Investment Trusts (REITs) using an approach suggested by French and Roll (1986), as extended by Tuluca et al (2003). In general, we find evidence that the effects of $9 / 11$ did not have a fundamental effect on real estate stock prices. In other words, the effect of the terrorist attack was financial and so transitory.

The remainder of the paper is organised as follows. The next section discusses the economic impact of the attack on the World Trade Center had on the US in general and real estate markets in particular. Section 3 describes the methodology and data used in this study to test whether the effect of 9/11 on REITs was fundamental or purely financial. Section 4 reports the empirical findings and Section 5 concludes the study.

\section{THE IMPACT 9/11 ON REAL ESTATE MARKETS}

On the morning of Tuesday 11 September 2001, the United States was hit by a set of unprecedented terrorist attacks, calculated to inflict massive civilian casualties and damage. Four hijacked commercial jets crashed, into the World Trade Center towers in Manhattan, which collapsed shortly thereafter, one on the Pentagon in Washington DC, and the last one in Pennsylvania. Over 3,000 people were killed, including hundreds of rescue personnel, Lenain et al (2002).

The 9/11 attacks inflicted casualties and material damages on a far greater scale than any terrorist aggression in recent history. The destruction of physical assets was estimated in the national accounts to amount to $\$ 14$ billion for private businesses, $\$ 1.5$ billion for State and local government enterprises and $\$ 0.7$ billion for Federal government. Rescue, cleanup and related costs have been estimated to amount to at least $\$ 11$ billion. Lower Manhattan lost approximately 30 percent of its office space and scores of businesses disappeared. Close to 200,000 jobs were destroyed or relocated out of New York City, at least temporarily (DRI-WEFA (2002)).

Beyond the direct property losses of $\$ 20$ $\$ 30$ billion, 300 businesses were directly affected by the attack. Buildings that were destroyed, structurally damaged and non-structurally damaged buildings or buildings requiring expensive cleaning for asbestos dust, totalled between 27-29 million square feet, however, this comprised less than four percent $(<4 \%)$ of the Manhattan, New York office market (Insignia/ESG, 2001). When viewed only from the loss of office space from a national and international standpoint, in absolute terms, the loss was even less significant. Available vacant and subleaseable space in the area roughly equalled the amount of space destroyed or damaged, with many companies choosing to relocate in the same office market. For instance, the local vacancy rate in Man- 
hattan in September 2000 was approximately 25.5 million square feet with additional sublease space expected to be available as subleaseable/available space due to the failure of dotcom companies to take up space.

However, the impact on the financial markets was swift and pronounced, stock prices tumbled, spreads between corporate and government bond yields, as well as spreads between emerging market and US bond index yields widened. Implied volatility as derived from traded options on stock market indices, government bond prices, short-term interest rates, exchange rates and commodities spiked upwards. Nonetheless, by the end of 2001, and not unlike during earlier wartime episodes, equity prices had bounced back vigorously, in many cases to well above their pre-9/11 levels, spreads generally narrowed and implied volatility declined significantly (Lenain et al, 2002). All of which suggests the impact on returns was short lived.

Baen (2003) argues that the terrorist attack added another dimension to property investment risk in the US and has serious implications for the future value and net operating income (NOI) to institutional, investmentgrade real estate. Kelly (2001) supports this argument but suggests that the impact of 9/11 would be felt across America to a greater or lesser extent depending on the economic base of the MSAs. The author arguing that the impact of 9/11 will have a pronounced effect on the national economy and so the impact on real estate, in a given area, depends on the exposure of the MSA to economic cycles. For instance, the author predicted that tourism cities, such as Las Vegas and Orlando, and hightech localities, including Austin, San Jose, San Diego, will experience an immediate and steep contraction into 2002, with a sharp rebound in 2003. In contrast, some MSAs including Detroit, St. Louis, Kansas City, and Miami with significant import/export exposure or ties to manufacturing industries will face a sever and prolonged downturn. In particular, Kelly (2001) sees New York City facing a long last- ing contraction, where the local economy does not recover to its 2001 level of employment until 2004. However, by the first quarter of 2002 Insignia/ESG reported that the New York real estate market was showing signs of recovery following the short recession of 2001 .

Baen (2003) also suggests that the reduced demand for real estate due to $9 / 11$ will be accelerated particularly in the high-rise CBD "trophy" office buildings that could be possible targets in the US or the world. Indeed, Grant (2002) predicted that landlords and/or tenants in "Trophy Property" high-rise buildings will be forced to pay much higher insurance costs $(300 \%)$ to stay in the central business districts. However, Miller et al (2003) find that there was no significant increase in vacancy rates in tall and trophy buildings across the major cities of the US although New York showed modest and negative effects on vacancy rates. The survey evidence by Miller et al (2003) indicating that the impact on tall and trophy buildings should show little lasting effects, although the truly famous buildings have suffered as a consequence of 9/11. Miller et al (2003) also found that sublease activity increased in famous buildings and since increases in sublease activity leads to increases in vacancy rates the authors argue that 9/11 had a negative effect on tall and trophy office markets. This is supported by Dermisi (2005) who finds that in Chicago which contains three of the four tallest buildings in the US (Sears Tower (first); Aon Center (third) and the John Hancock Center (fourth)) that although security measures were immediately heightened in the buildings after the terrorist attacks some tenants still vacated their office space as a direct consequence of the increased risk, with the terrorist attacks having a continuing and significant impact on vacancy and sublease vacancy rates in all three buildings. Additionally, even though gross rental rates have been kept stable, in an effort to increase demand and lower vacancy levels, the three buildings are still suffering. Dermisi (2005) concludes that "the psychological and economic effect of terrorist attacks on tenants of high-rise 
office buildings and their immediate areas is significant".

In summary, the impact of the 9/11 attacks was to severely increase the uncertainty of returns in financial markets in the US but was in the main short lived. However, the impact of $9 / 11$ on real estate returns is potentially more damaging and longer lived, especially for trophy buildings across the US. The following section therefore tries to quantify the impact of $9 / 11$ on real estate returns to sort out whether the effects were short or long lasting, i.e. financial or fundamental.

\section{METHODOLOGY AND DATA}

The methodology used to determine whether the effects of the 9/11 crisis were fundamental or purely financial is that suggested by French and Roll (1986). French and Roll (1986) focused on the sharp drop in the hourly volatility of returns when exchanges are closed. They noted that if hourly stock return variances were constant across trading and non-trading periods and if returns are independent and identically distributed (i.i.d.), the variance of weekend returns (i.e., Friday close to Monday close) would be tree times the variance of weekday returns (e.g., Tuesday close to Wednesday close). The observed ratio of weekend variances to weekday variances of only 1.107 , rather than 3.0 , suggests that prices are much more volatile when markets are open. French and Roll (1986) hypothesized that the higher volatility during trading hours results from either information (both public or private) that arrives primarily when markets are open or noise trading that also occurs only during market hours.

A major difference between information and noise trading, according to French and Roll, is that information-based changes in stock prices persist while noise trading effects (the result of trading errors, miss-pricing, and overreaction) tend to be short-lived and reversed in subsequent periods. Following Perry (1982), French and Roll discriminate between the ef- fects of information and noise trading on volatility by comparing daily return variances with the daily variances implied by variances for longer holding periods.

Tuluca et al (2003) extend this concept and suggest that the effects of information and noise trading on volatility can be detected by comparing the actual return variances of any shorter period with the implied variances derived from longer holding period, and use this idea to test the impact of the Asian crisis on international stock markets by comparing the actual daily return volatility versus implied daily volatility derived from monthly data. We follow this approach in the current paper and test the impact of $9 / 11$ on real estate returns by examining the differences of post- and precrisis variance ratios and interpret an increase in the difference as a fundamental (informational) effect and a decrease as a purely financial (noise trading) effect.

The study, therefore, needs daily data from the US. However, private real estate data is only available on a quarterly basis. In contrast, performance in the public market is easier to measure, since daily share prices are readily available from the National Association of Real Estate Investment Trusts (NAREIT). The data composed of an overall REIT index (ALLREITs) and three sub-indexes: (1) Equity REITs (EREITs), (2) Mortgage REITs (MREITs) and (3) Hybrid REITs (HREITs). Since the event is on Tuesday 11th September 2001 we chose the following preand post-crisis periods: pre- Monday 13 March 2000 - Monday 10 September 2001 (391 daily prices corresponding to 390 daily log returns), 18 monthly prices (2nd Monday of the month, corresponding to $18 \mathrm{log}$ returns): post- Wednesday 12 September 2001 - Wednesday 14 March 2003 (391 daily prices, 390 daily log returns), 18 monthly prices (2nd Tuesday of the month, corresponding to 18 log returns).

However, in using public market data to represent the performance of real estate a key question to be faced is whether REITs are a stock or property? It can be argued that the 
performance of REITs is ultimately dependent upon the underlying private market in that the asset values of the companies depend upon the capital value of the real estate owned, the ability to pay dividends depends upon the NOI from the property and the ability to trade profitably depends on increases in capital values which, in turn, depend on rental change and expectations of future growth. As a result, a close link between the public and private real estate might be expected. Nonetheless, the return behaviour of REIT returns is, in many ways, more similar to that of other equities (particularly small cap stocks) than of the underlying private real estate. Certainly, a number of studies have shown that REIT returns have much closer contemporaneous correlations with the stock market than with the underlying real estate market. Typical coefficients range between 0.65-0.85. Although, more recent statistical evidence finds that the equity component seems to be consistently shrinking over time while the sensitivity of REIT returns to the private real estate showed a significant increase in the 1990s (Gordon and Canter (1999) and Clayton and MacKinnon (2001)). This implies that the behaviour of REIT returns and those of the private real estate has tended to converge since the early 1990s.

In addition, previous studies demonstrate that once the equity component from REIT returns is removed, the resulting residual series is much more closely related to private real estate; see Clayton and MacKinnon (2001), Liang and McIntosh (1998), Sanders (1998), Chiang and Lee (2002) among others. This correlation also rises as longer time periods are analyzed; see Campeau (1994), Glascock et al (2000), Li and Wang (1995), Grissom and Oppenheimer (1998), Liang and Naranjo (1999), Okunev et al (2000), Wilson and Okunev (1996) and Wilson et al. (1998) among others. Thus over longer periods of time, REITs tend to behave more like property, even allowing for the presence of a large equity component. These findings suggest that if we re- move the pure equity market component from the REIT returns, the resulting residual series tends to be highly correlated with direct real estate returns. In other words, despite their legal standing as public securities, once allowances are made for the influences of broad stock market effects and differences in the underlying real estate, REIT returns are more closely tied to the private real estate than the "raw" data suggests.

Regressing REIT returns on the returns of competing assets the residuals from this model should represent the real estate component of REIT returns. In our case, we specify that REIT returns are a function of large cap stock returns, small cap stock returns, value, growth indexes and bond returns. We estimate this model using conventional linear regression techniques and then compute the regression residuals. This residual series contains the real estate component of returns, with the influences of the stock and bond markets removed. Once this is done we represent the results in terms of differences of post- and precrisis ratios and interpret an increase in the difference as a fundamental (informational) effect and a decrease as a purely financial (noise trading) effect. Consequently, we focus on actual daily return volatility versus implied daily volatility derived from monthly data for the REITs. In other words, if security price changes result primarily from information changes that persist and if daily returns are independent and identically distributed (i.i.d.), the implied daily variances for a longer holding period, such as a month, would approximate the actual daily variances within the period. On the other hand, if daily returns reflect noise trading effects that tend to be short lived and reversed in subsequent periods, the implied daily variances for the longer period would be smaller than daily variances within the period. We represent the results in terms of differences of post- and pre- crisis ratios and interpret an increase in the difference as a fundamental (informational) effect and a decrease as a purely financial (noise trading) effect. 


\section{RESULTS}

Columns 1 and 2 of Table 1 present the preand post-9/11 crisis variances of daily returns in the four REIT indexes. Columns 3 and 4 show corresponding variances of monthly returns (implied daily variances). Column 5 (Post/Pre) shows the ratios of the post-crisis daily variance (column 2 ) of returns to the precrisis daily variance (column 1). A Post/Pre ratio of 1.76 for the ALLREIT market as a whole indicates that the variance of daily returns rose by $76 \%$ following the $9 / 11$ crisis. Variances rose in two REIT types, EREITS (73\%) and MREITs (45\%), but fell by $7 \%$ for HREITS. For the 4 REIT types, the average percentage increase in the variance of daily returns was $47 \%$. We use an F-test of variance equality to assess if variances are statistically different in the post-pre crisis periods, with all but HREITs showing significant increases at the $1 \%$ level. In other words, 9/11 had a significant impact or return uncertainty for most REIT security process except Hybrid REITs (HREITs).

Column 6 (Post/Pre) shows the ratios of post-9/11 to pre-9/11 variances using the monthly returns from columns 4 and 3, respectively. As with the daily variances, monthly (implied daily) variances increased following the attack on the World Trade Centre by more than $7 \%$ for ALLREITs and $11 \%$ for EREITs, but fell by $3 \%$ for MREITs and $45 \%$ for HREITs and by an average $8 \%$ overall. Using an Ftest to assess if the monthly variances are statistically different in the post-pre crisis periods, none of the REIT indexes show a significant increase at the usual levels of significance. This suggests that the attack on the World Trade Center on 9/11 did not have a significant impact on the uncertainty on real estate securities in the US in the long term.

Tuluca et al (2003) argue that the increase in volatility in the post-9/11 period compared with the pre-9/11 period could result from either a fundamental change, due to information flows, or noise trading due to increased uncertainly which is transitory. Therefore, was the effect of the attack on the World Trade Center fundamental or transitory? In order to answer this question we compare the post-crisis increases in monthly (implied daily) variances (column 6 ) versus the post-crisis increases in daily variances (column 5), the results shown in column 7 . As can be readily appreciated the increase in monthly (implied daily) market volatility for all the REITs markets was less than the actual daily variance, the largest decrease by HREITs (40\%) and the least by MREITs (33\%) with an average decline of $37 \%$. Thus, we conclude that the effect of 9/11 on real estate in the US was financial and transitory rather than fundamental and persistent.

Table 1. Volatility of Actual and Implied Daily Volatility in US REIT Indexes: Pre- and Post-9/11

\begin{tabular}{|c|c|c|c|c|c|c|c|}
\hline & \multicolumn{2}{|c|}{$\begin{array}{l}\text { Daily } \\
\text { Variances }\end{array}$} & \multicolumn{2}{|c|}{$\begin{array}{l}\text { Monthly } \\
\text { Variances }\end{array}$} & \multirow{2}{*}{$\begin{array}{l}\text { Daily } \\
\text { Ratio } \\
(5=2 / 1)\end{array}$} & \multirow{2}{*}{$\begin{array}{l}\text { Monthly Ratio } \\
\text { (Implied Daily } \\
\text { Variances) } \\
(6=4 / 3) \\
\end{array}$} & \multirow{2}{*}{$\begin{array}{l}\text { Monthly (Post/Pre } \\
\text { Ratio), Daily Implied } \\
\text { Versus Actual Variance } \\
7=(6-5) / 5\end{array}$} \\
\hline & $(1)$ & $(2)$ & (3) & (4) & & & \\
\hline REIT & Pre & Post & Pre & Post & Post/Pre & Post/Pre & $\%$ change \\
\hline AllREITs & 0.23 & 0.41 & 0.23 & 0.25 & $1.76^{* *}$ & 1.07 & -39.45 \\
\hline EREITs & 0.25 & 0.43 & 0.23 & 0.26 & $1.73 * *$ & 1.11 & -36.18 \\
\hline MREITs & 0.72 & 1.04 & 0.56 & 0.55 & $1.45 * *$ & 0.97 & -33.25 \\
\hline HREITs & 0.72 & 0.67 & 0.76 & 0.42 & 0.93 & 0.55 & -40.52 \\
\hline Average & 0.48 & 0.64 & 0.45 & 0.37 & 1.47 & 0.92 & -37.35 \\
\hline
\end{tabular}

Notes: ** indicates significance at the $1 \%$ level 


\section{CONCLUSIONS}

The initial view of the terrorist attacks of 9/11 was that they would have a serious impact on the economy of the US in general and the New York in particular. However, with hindsight we can see that the US economy was already suffering and the 9/11 attacks did not have a significant effect on economic growth either nationally or in New York. Nonetheless, commentators argued that the effect of 9/11 terrorists attacks could be especially hard for real estate markets as it would raise uncertainty and so hurt the NOI of institutional investment-grade real estate, which suggests that the effects of the attack on the World Trade Center could be fundamental and long lasting for real estate securities. In contrast, others argued that when catastrophic events, such as the attack on the World Trade Center on $9 / 11$, occurs investor risk aversion increases dramatically but that the increase is only short lived. This implies that the 9/11 attacks would have only a financial impact on real estate security returns and so would be transitory. In other words, the effects of the 9/11 attacks on real estate securities could be either financial and persistent or fundamental and transitory.

In order to discriminate between fundamental and financial effects of major events, such as $9 / 11$, on real estate securities prices we adopt the approach suggested by French and Roll (1986), as extended by Tuluca et al (2003) using data from the post- and pre- crisis period for a number of REIT indexes. In particular, we examine the variance ratios of daily and monthly data and interpret an increase in the difference as a fundamental (informational) effect and a decrease as a purely financial (noise trading) effect. In general, we find that the greatest increases in volatility were at the daily, rather than monthly, frequencies which suggests that much of the increased volatility following the 9/11 crisis reflected noise trading effects rather than any fundamental impact on future capital values or expected earnings of US real estate securities. Thus we con- clude the impact of $9 / 11$ on US real estate securities was financial and transitory, rather than fundamental and persistent.

\section{REFERENCES}

Baen, J. (2003) The Implications of September 11, 2001 and Terrorism on International Urban Form and Various Classes of Real Estate, Presented at the American Real Estate Society (ARES) Meeting, Monterrey, April.

Campeau, F. (1994) A Microstructure Analysis of the Information on Securitized and Unsecuritized Commercial Real Estate Markets, Cambridge University Phd.

Chiang, K. C. H. and Lee, Ming-Long (2002) REITs in the Decentralized Investment Industry. Journal of Property Investment and Finance, 20(6), p. 496-512.

Clayton, J. and MacKinnon G. (2001) The TimeVarying Nature of the Link Between REIT, Real Estate and Financial Returns. Journal of Real Estate Portfolio Management, 7(1), p. 43-55.

Dermisi, S. V. (2005) Tenant Reaction Patterns to the threat of a Terrorist Attack after September 11, 2001, in Downtown Chicago Office Market, Presented at the American Real Estate Society (ARES) Meeting, Santa Fe, April.

DRI-WEFA (2002) Financial Impact of World Trade Center Attack, Prepared for the New York State Senate Finance Committee, January.

French, K. R. and Roll, R. (1986) Stock Return Variances: The Arrival of Information and the Reaction of Traders. Journal of Financial Economics, 17(1), p. 5-26.

Glascock, J., Chiuling, L. and So, R. (2000) Further Evidence on the Integration of REIT, Bond and Stock Returns. Journal of Real Estate Finance and Economics, 20(2), p. 177-194.

Gordon, J. N. and Canter, T. A. (1999) International Real Estate Securities: A Test of Capital Market Integration. Journal of Real Estate Portfolio Management, 5(2), p. 161-170.

Grant, P. (2002) Market for Trophy Property Slows as Insurance Choices Start to Fall. The Wall Street Journal, Eastern edition; Jan 11, 2002; B.8.

Grissom, T. and Oppenheimer, P. (1998) Frequency Space Correlation Between REITs and Capital Market Indices. Journal of Real Estate Research, 16(3), p. 291-310. 
Insignia/ESG, Inc. (2001) The Impact of the September $11^{\text {th }}$ Tragedy. Real Estate Issues, 26(3), p. $1-4$.

Kaminsky, G. L. and Schmukler, S. L. (1999) What Triggers Market Jitters?: A Chronicle of the Asian Crisis. Journal of International Money and Finance, 18(4), p. 537-560.

Kelly, H. F. (2001) The Post Attack Economy: An Outlook Across America. Real Estate Issues, 26(3), p. 5-8.

Lenain, P., Bonturi, M. and Koen, V. (2002) The Economic Consequences of Terrorism, OECD Working paper ECO/WKP (2002) 20.

Li, Y. and Wang, K. (1995) The Predictability of REIT Returns and Market Segmentation. Journal of Real Estate Research, 10(4), p. 471-482.

Liang, Y. and McIntosh, W. (1998) REIT Style and Performance. Journal of Real Estate Portfolio Management, 4(1), p. 69-78.

Ling, D. C. and Naranjo, A. (1999) The Integration of Commercial Real Estate Markets and Stock markets. Real Estate Economics, 27(3), p. 483-515.

Mueller, A. G. and Mueller, G. R. (2003) Public and Private Real Estate in the Mixed-Asset Portfolio. Journal of Real Estate Portfolio Management, 9(3), p. 193-203.

Miller, N. G. Markosyan, S., Florance, A., Steveson, B. and Op't Veld, H. (2003) The 9/11/ 2001 Impact on Trophy and Tall Office Prop- erty. Journal of Real Estate Portfolio Management, 9(2), p. 107-125.

Myer, F. C. N. and Webb, J. R. (1993) Return Properties on Equity REITs, Common Stocks and Commercial Real Estate: A Comparison. Journal of Real Estate Research, 8(1), p. 87-106.

Okunev, J., Wilson, P. and Zurbruegg, R. (2000) The Causal Relationship Between Real Estate and Stock Markets. Journal of Real Estate Finance and Economics, 21(3), p. 251-261.

Perry, P. R. (1982) The Time-variance Relationship of Security Returns: Implications for the Return Generating Stochastic Process. Journal of Finance, 37(3), p. 857-870.

Sanders, A. B. (1998) The Historical Behavior of REIT Returns: A Capital Market Perspective, in Garrigan, R. T. and Parsons, J. F. C. (eds.), Real Estate Investment Trusts, McGraw-Hill.

Tuluca, S. A, Zwick, B. and Seiler, M. J. (2003) International Versus U.S. Sector Diversification Strategies in the Wake of the Asian Crisis. American Business Review, 21(1), p. 67-74.

Wilson, P., Okunev, J. (1996) Evidence of Segmentation in Domestic and International Property Markets. Journal of Property Finance, 7(4), p. 78-97.

Wrolstad, M., and Krueger, T. (2003) The Impact of September 11 on Investors' Risk Aversion. Journal of Investing, 12(2), p. 72-80.

\section{SANTRAUKA \\ RUGSĖJO 11-OSIOS POVEIKIS JAV NEKILNOJAMOJO TURTO INVESTICIJŲ GRĄŽAI: FUNDAMENTALUS AR FINANSINIS?}

\section{Andrea GHENO, Stephen L. LEE}

Po Pasaulinio prekybos centro rugsėjo 11-ają atakų prieš JAV vertybinių popierių biržose ėmè staigiai kisti kasdienė investicijų grąža. Šis augimas gali rodyti, kad fundamentaliai pakito tokie ekonominiai kainas lemiantys veiksniai, kaip laukiamas pelnas, palūkanų normos, realus augimas ir infliacija. Kita vertus, augantis kitimas gali tiesiog perteikti didesnio finansinių rinkų netikrumo poveikį. Todẻl šiame darbe siekiama nustatyti, ar Pasaulinio prekybos centro atakų pasekmiu poveikis JAV nekilnojamojo turto investicijų grąžai buvo fundamentalus, ar tik finansinis. Siekiant tai išsiaiškinti, palyginta kelių JAV nekilnojamojo turto investicijų indeksų grąža prieš rugsejo 11-osios krizę ir po jos. Nustatyta, kad šios atakos pasekmès padarė finansinį poveiki nekilnojamojo turto investicijų grąžai, ir dèl to šis poveikis buvo laikinas. 